\title{
Dilemma and Countermeasures of Art Design Education in Colleges and Universities Under COVID-19 Epidemic Situation
}

\author{
Taking the Course of "Foundation of Graphic Software" as an \\ Example
}

\author{
Lijuan Xiong ${ }^{1, *}$
}

${ }^{1}$ School of Fine Arts and Design, Chengdu University, Chengdu, Sichuan, China

*Corresponding author. Email: xiongxiong_1980@yeah.net

\begin{abstract}
Against the background of novel corona virus pneumonia, this article starts from the background of online teaching of art design major in colleges and universities, expounds the educational plight faced by online teaching and analyses the causes of the dilemma. From the three aspects of teaching design, teaching practice and assessment methods, this paper puts forward solutions which emphasize on enhancing the sense of class ceremony to enhance the students' recognition of online classes, and strengthen the design for life, design for fighting against the epidemic, to improve the students' participation. The solutions put forward in this paper have been applied in the course of "Foundation of Graphic Software" in the distance network teaching, and the effect is good.
\end{abstract}

Keywords: art design major, online courses, education plight, measures

\section{INTRODUCTION}

2020 is destined to be extraordinary. On January 12 , 2020, the National Health Commission of the people's Republic of China issued Announcement No. 1 in 2020, which confirms that the pneumonia caused by novel corona virus is included in the class B infectious diseases stipulated in the Law of the People's Republic of China on Prevention and Control of Infectious Diseases, and preventive and control measures for class A infectious diseases are taken. At the end of the winter vacation, on February 12, 2020, the General Office of the Ministry of Education and the General Office of the Ministry of Industry and Information Technology issued the Notice on the Work Arrangement of "No Suspension of Classes" during the Extension of Primary and Secondary Schools. After delaying the opening time, colleges and universities also issued the notice of "no suspension" in the middle and late February. At present, online teaching has been carried out for nearly a month. As at 24:00 on March 13, 2020, novel corona virus pneumonia has been diagnosed to 12094 cases. [1] The epidemic control in China is on a good trend, but it is undeniable that the education under the epidemic will last for several months.

In February 2019, the Central Committee of the Communist Party of China and the State Council issued
China education modernization 2035, calling on all departments to implement it seriously, which focuses on the prominent problems and weak links in the development of education. Based on the current situation and the long-term perspective, the eighth of the ten strategic tasks for the modernization of education is proposed to speed up the educational reform in the information age. [2] In the early stage, the implementation of policies, the construction of MOOC courses in the past decade and the development of China's powerful information network has provided the basic conditions for online education in response to the epidemic.

How to smoothly promote the normal progress of education and teaching under the epidemic situation has become the concern of many educators.

\section{AN ANALYSIS OF THE EDUCATIONAL PLIGHT AND ITS CAUSES UNDER THE EPIDEMIC SITUATION}

Through nearly one month of online teaching, I, as a first-line teaching staff, analyze the educational plight and the causes of the plight from four aspects: physical environment, teaching environment, curriculum characteristics, and psychological situation. 


\section{A. Physical environment}

When students study at home, the family needs to create a good learning environment for them. Each student's family environment is different, which cannot guarantee that all students have a relatively independent learning space. At home, the attention of family members to curriculum learning directly affects the construction of students' learning atmosphere.

\section{B. Teaching environment}

The dilemma of teaching environment mainly lies in the basic conditions of online teaching. The jam phenomenon caused by the unstable network or the long-term use of communication software appear on both teachers and students, which is a big interference factor in the teaching process.

\section{Course characteristics}

The art design education in colleges and universities has a strong practicality, especially for the software tool courses similar to "The foundation of Graphic Software", and it is necessary to carry out practical operation exercises in order to test students' mastery of knowledge. In the teaching of art design, teachers should not only grasp the students' attention and help them to improve their professional theory and technical skills, but also create a relaxed, efficient and knowledge acquisition atmosphere, to carry out the teaching of professional knowledge. In the course preparation stage, the course requires a reasonably configured computer and the installation of a corresponding version of the software. If it is offline teaching, these things have been installed in the design laboratory. But for online teaching, all the students need to solve their own problems, such as the low configuration of the computer and the unfamiliar installation of computer software. In the course, students will encounter a variety of problems in the operation process, and the answer to the problems cannot be as timely as offline.

\section{Psychological situation}

In the nearly one month of home-based learning under the epidemic, besides the lack of familiar offline learning places, students will inevitably have no psychological discomfort in the process of online learning. At the beginning of the course, most of the students can adjust their psychological state gradually to adapt to the new arrangement. A small number of students will have resistance because of the actual situation. For example, some students do not take their computers home during the holidays, and the family situation does not allow them to buy new computers. In the course of teaching, because of the long-term use of electronic equipment, students are more prone to "wandering". The cause of this phenomenon is not only the visual fatigue of electronic devices, but also the habit of using mobile information for a long time, which leads to distraction.

\section{SOLUTIONS}

In this section, we discuss three aspects about teaching design, teaching practice and assessment methods to solve the educational plight.

\section{A. Teaching design}

Curriculum design plays an important role in the teaching process, which can solve most of the problems. We discussed how to deal with the plight of the epidemic from three aspects of curriculum design which include course preparation, Teaching process and course Q\&A (Question and Answer).

1) Course preparation: The preparation before the course mainly includes the overall structure of the course, the content of the course and the arrangement of time.

The overall structure of the course is mainly guided by the curriculum syllabus, and the reasonable allocation of teaching content is carried out in combination with the teaching materials. In this process, teachers systematically integrate this course with the later courses according to the necessary ability requirements of students proposed by the teaching syllabus and professional courses. Teachers should prepare lessons from both static and dynamic aspects. The preparation of static course content includes the daily preparation of course outline, teaching plan, course calendar, PowerPoint slide, etc.; the dynamic course content is arranged and uploaded in accordance with many excellent "MOOC" resources. In the production of PowerPoint slide, the teacher should strive to show the most basic course content, best to demonstrate the role of basic functions and tools as the main content, and strive to achieve "selection, meticulous, foundation oriented". In the process of making PowerPoint slide, the teacher should try to make it clear and logical, and grasp the time well to show one by one in the demonstration process. On the one hand, it enables students to understand the course content more intuitively, and on the other hand, it also avoids the phenomenon of viewing delay caused by factors such as network jam. By arranging the time nodes of course information upload, the static course content related to the syllabus can be uploaded to the platform first, so that students can have a comprehensive grasp of the course. Strive to complete the task of uploading static course content such as PowerPoint files the day before the course. On the one hand, it is convenient for teachers to make appropriate adjustments according to the teaching situation of the day; on the other hand, it is convenient for students to download and watch relevant videos in advance, so that students can better carry out the course learning. 
2) Teaching process: In the course of teaching, the teacher mainly considers three aspects: the sense of ceremony, the organization of teaching and the timely interaction of teaching.

It needs to pay attention to the sense of ceremony in class. In the online teaching process, due to the lack of school bell and relatively centralized group class environment, there is no sense of ceremony in class. Teachers can use the way of starting the test 10 minutes in advance to let students enter the classroom, to improve the sense of ceremony in class; Pay attention to the teaching organization. In the course of teaching, because most students do not have their own teaching materials, the teachers should take PowerPoint slide as the main line. In addition to clearly emphasizing the key points and difficulties of the teaching content in PowerPoint files, teachers can organize the key content of the course by repetition of key points or curriculum review during the teaching process. Pay attention to the timely interaction of teaching. Online teaching does not have real-time interaction like offline teaching. In the process of online teaching, students become unfocused easily. On the one hand, teachers can control the rhythm of a key question in the course of teaching, leave a blank in time for students to recall what they have just learned, or ask students to answer questions, so as to increase students' participation in the classroom and it also avoids the situation situations where only the teacher speaks. On the other hand, in the course of teaching, teachers can further interact with students by commenting on homework in class, and leaving a message is also a good way to interact with students.

3) Course $Q$ \& $A$ : Students inevitably have questions in the learning process, which requires teachers to answer them in a targeted and timely manner. Teachers can use the advantages of online education to reply in a static and dynamic way.

It needs to pay attention to reply in a static way. In the process of online teaching, all questions raised by students will be saved as chat records. Teachers can answer students' questions one by one through records, without any omission. Teachers can use the function of discussion area provided by the learning platform to publish students' questions and answers. On the one hand, the answers can be published in a fixed and open area; on the other hand, it is convenient for students to inquire in case of relevant problems. Pay attention to reply in a dynamic way. Static response is suitable for simple conceptual questions, but for operational questions, teachers need to use dynamic response to answer, combined with online teaching screen sharing for demonstration.

\section{B. Curriculum practice}

Aiming at the problems in curriculum practice, they are mainly solved through the combination of hierarchical management of curriculum practice structure and the life-oriented curriculum practice content.

The curriculum practice is planned and designed at different levels. According to the learning content, it can be divided into four ways by using different time nodes: classroom practice, comprehensive training, phased course assignment and application course assignment. The class practice mainly carries out a series of targeted operation training on the knowledge points of the course. Its design features are strong pertinence, low difficulty, easy to get started, short time of practical operation, and the reasonable use of knowledge points to achieve the purpose of improving students' learning interest; Compared with the classroom practice, the comprehensive training is less targeted, which mainly focuses on the ability of students to use knowledge points flexibly in sections; the phased curriculum practice mainly focuses on the comprehensive training of the phased curriculum content on a weekly basis, which can be included in the usual assessment range; The application course assignment mainly enables students to make full use of the powerful functions of the software in advance to do well in the training of professional courses such as photography, poster design, logo design and so on which students need to face in the later period. The multi-level structure of the curriculum practice link makes the classroom practice highly targeted. And the teaching content of each course is designed with targeted classroom practice, so that students are really "busy" in the classroom. In the process of completing different exercises, students should integrate the ways of centralized learning and offline self-study, and take problem-solving as the guide to go deep into the course learning.

The content of curriculum practice is fully consistent with students' life. When Photoshop course is defined as a tool, it has been the basic requirement of the course to be able to have a good command of software. Practicality is a necessary feature of the tool course. Therefore, in the content selection of the course practice, students are mainly guided to design for themselves, for their families, for the public interest and for the country.

The content of the course is from small to large. For example, in the practice of using tools in the early stage of teaching, when students use the rectangular selection box of the toolbar to draw, the knowledge points involved are relatively simple. In order to improve the students' interest in participation, the project is designed to use their own photos or their favorite photos to form a heart shape. Students are highly motivated to participate, and some students save this assignment as their own screensaver or signature. In the middle stage of learning, when teaching the color matching function, 
students are guided to carry out the multi-color processing for the old photos at home. When teaching the filter, let the students beautify their own or family photos, such as slimming and wrinkle removing for the characters in the photos to complete the practice of the course content. At the end of the learning, the practical content of the course is adjusted to the design of public posters suitable for epidemic situation now. The content setting of curriculum practice is based on letting students "use what they have learned, gain what they have practised, feel something, and practice something" to truly realize the close relationship between learning and life.

\section{Assessment method}

In response to the epidemic, the assessment standard of online teaching mode is based on the previous assessment standard of 1:3:6 of attendance, regular assignments and comprehensive assignments. For attendance assessment, due to the delay of attendance assessment in the process of online check in system caused by various reasons, it is necessary to reduce the reference of system attendance assessment as the standard and turn to the actual online number of students in the classroom as the final attendance statistics. In order to make the attendance assessment transparent and open, it will be publicizing the class by means of the screenshot during breaks. As for the usual assessment, because the course content has added the "MOOC" video that was not used in offline teaching, the online learning situation that can be included in the usual assessment has also been added to the assessment of students, and the proportion of the usual assessment has also been increased. The revised assessment standards are detailed as: attendance $10 \%$, regular assignments (including video learning) 45\%, comprehensive assignments $45 \%$. For those students who can't submit their homework in time due to the lack of actual situation, delayed submission and diversified standard submission are adopted.

\section{CONCLUSION}

If education prospers, the country prospers; if education is strong, the country is strong. COVID-19 pneumonia not only tests the art and design education in Colleges and universities, but also tests the ability of teachers, students, schools and education management departments to cope with emergencies when they have adapted to the traditional offline teaching for a long time. At the same time, it also tests the basis of modern education and teaching in China. I believe that through the concerted efforts of the whole nation, we can not only overcome the epidemic, but also gain valuable online teaching experience, which can lay a solid foundation for the education reform in the information age. Under the impact of the epidemic, this paper analyses the educational difficulties and the causes of online teaching of art design major in Colleges and universities, and the same time, it presents the countermeasures from three aspects: teaching design, teaching practice and assessment methods, which will enhance the students' recognition of online class through the sense of class ceremony, and will enhance the students' participation through strengthening the idea of design for life, and design for fighting against the epidemic. The solutions put forward in this paper have been applied in the course of Foundation of Graphic Software for distance network teaching, and the effect is good.

\section{Acknowledgment}

This research was financially supported by the General Project of Higher Education Personnel Training Quality and Teaching Reform of Sichuan Education Department in 2018-2020 (Grant No. JG2018-785), the General Project of Sichuan Provincial Department of Education (Grant No. 18SB0148), the Research Center of Urban and Rural Education Development( Grant No. TCCXJY-2020-D43).

\section{References}

[1] National Health and Health Commission of the people's Republic of China: Up to 24 March 13th novel coronavirus pneumonia epidemic situation, http://www.nhc.gov.cn/xcs/s3574/202003/7a9695f4ccb94c88a3 8061145cb438aa.shtml, 2020-03-24.

[2] Printed and distributed by the CPC Central Committee and the State Council 'Education modernization in China 2035'. China Electronics Education, vol. 2019, no. 2, pp. 5, 2019.

[3] L. Zhang, S. H. Zhang, On the teaching of art design specialty based on the mode of 'MOOC + smart classroom'. Art Education, vol. 2019, no. 7, pp: 178-180, 2019.

[4] W. F. Min, Promoting the modernization of education and releasing the vitality of Education. Education and Teaching Research, vol. 2020, no. 1, pp:1-2, 2020 DOI:10.13627/j.cnki.cdjy.2020.01.001

[5] L. Zhang, S. H. Zhang, On the teaching of art design specialty based on the mode of 'MOOC + smart classroom'. Art Education, vol. 2019, no. 7, pp: 178-180, 2019.

[6] W. F. Min, Promoting the modernization of education and releasing the vitality of Education. Education and Teaching Research, vol. 2020, no. 1, pp:1-2, 2020. DOI:10.13627/j.cnki.cdjy.2020.01.001. 